\title{
Is Ventricular Arrhythmias the End for All Conditions?
}

\author{
Ahmet Goktug Ertem Mehmet Akif Erdol Koray Demirtas Sefa Unal \\ Mustafa Karanfil Cagri Yayla \\ Department of Cardiology, Ankara City Hospital, Ankara, Turkey
}

Dear Editor,

We read the article titled "Abnormal Dispersion of Ventricular Repolarization as a Risk Factor in Patients with Human Immunodeficiency Virus: Tp-e Interval, Tp-e/QTc Ratio" by Evren et al. [1] with interest. The authors evaluated the changes in Tp-e interval, Tp-e/QT, and Tp-e/corrected QT (QTc) ratios, and traditional electrocardiographic features of electrical dispersion in adults infected with human immunodeficiency virus (HIV); their study revealed that the cTp-e interval, Tp-e/QT, and $\mathrm{Tp}$-e/QTc ratios were prolonged and correlated to the severity of the disease in HIV-infected patients.

Previous studies have revealed that the Tp-e interval, the Tpeak-Tend interval (Tpe), and the interval from the $\mathrm{T}$-wave peak to the end of the $\mathrm{T}$ wave are related to arrhythmogenesis, specified as an index of total dispersion of repolarization [2]. Prolonged Tp-e interval is predictive for ventricular arrhythmias and mortality [3]. Unal et al. [4] showed that HIV-infected patients receiving combination antiretroviral therapy were associated with longer Tp-e interval and Tp-e/QTc ratio and correlated positively with the duration of disease and the electrophysiological abnormalities, and negatively with the CD4 count.

However, there was no information on the medical status of patients with HIV, duration of the disease, and why hsCRP levels were higher in the patient group. The patients were in the active phase of infection. We think that these are important data for the study.

\section{Conflict of Interest Statement}

The authors declare that they have no potential conflicts of interest concerning the research, authorship, and publication of this article.

\section{Funding Sources}

The authors received no financial support for the research, authorship, and publication of this article.

\section{Author Contributions}

All authors contributed to the conception of the work and drafted the manuscript, gave final approval, and agreed to be accountable for all aspects of the work in ensuring that questions related to the accuracy or integrity of any part of the work are appropriately investigated and resolved.
C 2021 The Author(s)

Published by S. Karger AG, Basel

This is an Open Access article licensed under the Creative Commons Attribution-NonCommercial-4.0 International License (CC BY-NC) (http://www.karger.com/Services/OpenAccessLicense), applicable to the online version of the article only. Usage and distribution for commercial purposes requires written permission.
Correspondence to:

Ahmet Goktug Ertem, agertem@ @otmail.com 


\section{References}

1 Unal Evren E, Cekirdekci EI, Evren H, Suer K, Sarigul Yildirim F, Asan A, et al. Abnormal dispersion of ventricular repolarization as a risk factor in patients with human immunodeficiency virus: Tp-e interval, Tp-e/QTc ratio. Med Prin Pract. 2020;29:544-50.

2 Kors JA, Ritsema van Eck HJ, van Herpen G. The meaning of the Tp-Te interval and its diagnostic value. J Electrocardiol. 2008 NovDec;41(6):575-80.
3 Castro Hevia J, Antzelevitch C, Tornés Bárzaga F, Dorantes Sánchez M, Dorticós Balea F, Zayas Molina R, et al. Tpeak-Tend and TpeakTend dispersion as risk factors for ventricular tachycardia/ventricular fibrillation in patients with the Brugada syndrome. J Am Coll Cardiol. 2006 May 2;47(9):1828-34.

4 Unal S, Yayla C, Acar B, Ertem AG, Akboga MK, Gokaslan S, et al. Tp-e interval and Tp-e/ QT ratio in patients with Human Immunodeficiency Virus. J Inf Pub Health. 2018 JanFeb;11:35-8. 